\title{
Clinicopathological Parameters and Sialyltransferase Activity in Trypanosoma Congolense-Infected Sheep
}

\author{
${ }^{*}$ Y. S. Baraya, ${ }^{2}$ M. E. Sadiq, ${ }^{3}$ J. A. Atata, ${ }^{4}$ S. J. Enam, ${ }^{4}$ S. Adamu, ${ }^{5}$ K. B. Kadima, ${ }^{6}$ N. M. Useh \\ and ${ }^{4}$ K. A. N. Esievo \\ 1Department of Veterinary Pathology, Usmanu Danfodiyo University, Sokoto, Nigeria \\ ${ }^{2}$ Department of Biochemistry and Molecular Biology, Usmanu Danfodiyo University, Sokoto, Nigeria \\ ${ }^{3}$ Department of Veterinary Pathology, University of Ilorin, Ilorin, Nigeria \\ 4Department of Veterinary Pathology, Ahmadu Bello University, Zaria, Nigeria \\ ${ }^{5}$ Veterinary Teaching Hospital, Ahmadu Bello University, Zaria, Nigeria \\ ${ }^{6}$ Department of Veterinary Pathology, University of Agriculture, Makurdi, Nigeria \\ [Corresponding Author: E-mail: ysbgobir123@gmail.com]
}

\section{ABSTRACT}

Cleavage of erythrocyte surface sialic acid (SA) by the sialidase produced by trypanosomes is implicated in the pathogenesis of anaemia in African animal trypanosomiasis (AAT). Sialyltransferase (ST) mediates the attachment of SA to cell surface glycoproteins and glycolipids of desialylated erythrocytes. ST activities in Trypanosoma congolense-infected sheep and control groups were investigated and variations in their physio-biochemical properties were evaluated. Six (6) apparently healthy Nigerian Yankassa breed of sheep comprising of $T$. congolense-infected $(n=3)$ and non-infected $(n=3)$ groups were used for the experiment. Parasitaemia and packed cell volume (PCV) were determined daily over a 5-week period. Enzyme kinetics of partially purified ST from the thyroid gland were also evaluated. Anaemia (mean PCV $=18.83 \pm 0.71 \%$ ) was observed in the $T$. congolense-infected sheep when compared with the non-infected control group (mean PCV 39.75 $\pm 0.35 \%)$ and the observed differences were significant $(p<0.05)$ after five weeks post infection. Variations were also observed in the physio-biochemical properties $\mathrm{pH}$, temperature, activation energy) of the ST isolated from the $T$. congolense-infected and control sheep. This finding is believed to have been an induced response by the host to parasite's activity and could be exploited further as a possible target in the control of AAT.

Keywords: Anaemia, Sialic acid, Sialyltransferase, Sheep, Thyroid gland, Trypanosoma congolense

\section{INTRODUCTION}

African animal trypanosomosis (AAT) is a very complex and debilitating vector-borne disease of domestic and wild animals in sub-Saharan Africa (CFSPH, 2018). The disease is a major challenge to food security and public health and is widely known as sleeping sickness and 'nagana' in man and animals, respectively (Sulaiman and Adeyemi, 2010; WHO, 2021). In Nigeria, the most important trypanosome species are Trypanosoma brucei, $T$. congolense, $T$. vivax, and $T$. evansi in livestock, although $T$. brucei gambiense infect human beings (Abubakar et al., 2010). Tsetse flies are the most important vectors of transmission in AAT, although some Trypanosoma species have been reported to be mechanically transmitted by other biting flies
(WHO, 2021). Trypanosomal sialidase (SD) has been implicated in the pathogenesis of anaemia in AAT (Esievo, 1979). The enzyme is responsible for the cleavage of sialic acid (SA) from a wide range of sialic acid-containing cells including erythrocytes (Esievo, 1979; Pereira, 1983). Sialyltransferase (ST) is known to be involved in re-sialylation of erythrocyte surface in the course of trypanosomiasis; hence, playing important role in the recovery phase of anaemia in AAT (Esievo et al., 1986). Sialyltransferase activities have been reported in various tissues including liver and mammary glands (Alhadeff and Holzinger, 1979; Ellies et al., 2002; Paltrinier et al., 2012) and on cell surfaces (Porter and Bernacki, 1975; Wang et al., 2001). However, there is still paucity of information on the ST 
activity in trypanosomes infected and noninfected animals. Thus, in this study we compared the physio-biochemical properties of ST isolated from the thyroid glands of $T$. congolense-infected sheep and apparently healthy group.

\section{MATERIALS AND METHODS}

\section{Experimental Animals and Sample Collection}

Six (6) apparently healthy Nigerian Yankassa sheep aged between 1 and 2 years were used for the study. The animals were kept in a fly-proof pen to acclimatize for 2 months and carefully screened for internal and external parasites before the commencement of the study. These animals were later randomly grouped into $T$. congolense-infected and non-infected groups, each group containing 3 animals $(n=3)$. Experimental animals were fed with wheat offal, groundnut and cowpea hays and water was given ad libitum. Trypanosoma congolense (savannah strain) was obtained from the National Institute for Trypanosomiasis Research Vom, Nigeria. The $T$. congolense-infected group were inoculated via the jugular vein with $1 \times 10^{2}$ trypanosomes $/ \mathrm{mL}$. One (1) $\mathrm{mL}$ of blood was collected via the jugular vein on a daily basis for 30 days from $T$. congolense-infected and non-infected groups and transferred into vacutainers containing ethylene diamine tetra acetic acid (EDTA) for the detection and monitoring of parasitaemia, and determination of packed cell volume (PCV).

After 30 days post infection, $5 \mathrm{~mL}$ of whole blood was collected from the experimental animals into screw-capped test tubes without anticoagulant to obtain serum which was centrifuged at 5,000 rpm for 5 minutes and the supernatant transferred into serum vials and stored at $-20^{\circ} \mathrm{C}$ until used for ST assay. The experimental procedure followed the ethical guidelines for animal care in research of the Ahmadu Bello University Zaria, Nigeria. Experimental animals were subsequently humanely sacrificed and selected organs harvested for sialyltransferase enzyme isolation

\section{Partial Purification of Sialyltransferase}

Sialyltransferase from the thyroid, salivary glands and liver were isolated using Triton X-100 from $T$. congolense-infected and non-infected groups as described by Sticher et al. (1991). Thyroid gland which had highest enzyme (ST) activity was subjected to further purification steps.

\section{Ammonium Sulphate Precipitation}

Crude enzyme extract from the thyroid gland of $T$. congolense-infected and non-infected groups were precipitated by addition of ammonium sulphate up to $70 \%$ (w/v) saturation. The precipitate recovered after centrifugation was reconstituted in $20 \mathrm{~mL}$ phosphate buffered saline and dialyzed over night against three changes of the same buffer at $4^{\circ} \mathrm{C}$ (Hidari et al., 2005).

\section{Sialyltransferase Assay}

Sialyltransferase activity was determined using the method described by Křen and Thiem, (1997) with some minor modifications such as the use of pestle and mortar, Triton X-100 and Dowex column $1 \times 8$, (3cm length). Each assay mixture contained the following components: buffer system, bovine serum albumin, asialofetuin (acceptor substrate), cytidine monophoshate neuraminic acid (CMP-Neu5Ac) (donor substrate) and enzyme solution. The control tubes had no acceptor substrate.

\section{Ion Exchange Chromatography}

This was carried out using DEAE-cellulose (DE52) column $(1.6 \times 30 \mathrm{~cm})$. Two columns were set for the $T$. congolense-infected and non-infected groups. The flow rate of the columns was adjusted to $0.75 \mathrm{~mL} / \mathrm{min}$ and $5 \mathrm{~mL}$ fractions were collected in each tube. Tubes with highest enzyme activity were pooled.

\section{Gel Filtration}

This was carried out using Sephadex G-100. Two columns were similarly prepared as described for experimental groups for further enzyme fractions purification. Both columns had a flow rate of 0.4 $\mathrm{mL} / \mathrm{min}$. The eluates were collected in $5 \mathrm{~mL}$ fractions for sialyltransferase assay. 


\section{Optimum pH}

The activity profile of the partially purified ST from harvested thyroid tissue of $T$. congolense-infected and non-infected groups in terms of $\mathrm{pH}$ of maximum activity was determined. The enzymes activities were determined as described at $\mathrm{pH}$ range $4-8$ viz $5.0 \mathrm{mM}$ sodium acetate buffer $\mathrm{pH}$ 4-4.5; phosphate buffer $\mathrm{pH} \mathrm{6-7}$ and Tris-HCl buffer $\mathrm{pH}$ 7.5-8. The sialyltransferase enzyme activities versus $\mathrm{pH}$ was plotted to determine optimum $\mathrm{pH}$.

\section{Optimum Temperature}

Equal volumes $(25 \mu \mathrm{l})$ of the enzymes and substrates were incubated at intervals of $5^{\circ} \mathrm{C}$ for 30 minutes, at $25^{\circ} \mathrm{C}, 30^{\circ} \mathrm{C}, 35^{\circ} \mathrm{C}, 40^{\circ} \mathrm{C}, 45^{\circ} \mathrm{C}$ and $60^{\circ} \mathrm{C}$. The various tubes were cooled to room temperature and assayed for ST activities as described. A plot of ST activities against temperature was used to determine the optimum temperature.

\section{Activation Energy \\ Activation energy $\left(E_{a}\right)$ was deduced using the relationship $E_{a} / R=\ln K$, where $R$ and $\ln K$ are the molar gas constant and rate constant for the chemical reaction, respectively. Arrhenius plot for $E_{a}$ determination was obtained by plotting natural logarithm of the enzyme activity (In K) against the reciprocal of temperature (1/T) in Kelvin ( $\left.{ }^{\circ} \mathrm{K}\right)$ for the various temperature intervals.}

\section{Kinetic Studies}

The substrate (asialofetuin) concentration was varied over the range of $1-10 \mathrm{mg} / \mathrm{ml}$. The effect of substrate concentration on ST activities were carried out as outlined in the standard assay procedure. The kinetic constants, $\mathrm{Km}$ and $\mathrm{V}_{\max }$ for both enzymes were determined from LineweaverBurk reciprocal plot.

\section{Statistical Analysis}

Data from the study was computed as mean \pm standard deviation (SD) and analyzed using independent $T$ test for comparison between groups. $P<0.05$ was considered statistically significant.

\section{RESULTS}

\section{Parasitaemia}

Parasitaemia was observed 4-5 days' post infection in the $T$. congolense-infected group as shown in Figure 1. Peak parasitaemia was noticed on day 16 , with a sharp decline on days 17 and 18, and thereafter fluctuated moderately for the rest of the experimental period. $T$. congolense-infected animals had lower mean PCV values when compared with the non-infected group (Figure 2). The lowest mean PCV value $(18.3 \pm 2.1 \%$, day 30 of the experiment) was recorded in the $T$. congolense-infected group, while the highest mean PCV value $(48.5 \%$, day 1 of the experiment) was recorded in the noninfected group. The mean weekly PCV values in the two experimental groups were statistically significant. $(\mathrm{P}<0.05)$ (Table 1).

Table 2 shows the summary of purification of sialyltransferase from the thyroid glands of $T$. congolense-infected and the non-infected groups. The most effective of the purification steps was the use of Sephadex G-100 chromatography. With this purification step, enzyme yield was $13.7 \%$ and $16.6 \%$ for the non-infected and $T$. congolense-infected groups, respectively. The specific activity was $756.3 \mathrm{U} / \mathrm{mg}$ and purification fold of 4528 for thyroid gland samples of noninfected group. Similarly, the enzyme specific activity for the infected group was $566.67 \mathrm{U} / \mathrm{mg}$ and purification fold of 1045.50. On SDS-PAGE, the enzyme migrated either as a $49 \mathrm{KDa}$ or 56 $\mathrm{KDa}$ band for the $T$. congolense infected and non-infected groups, respectively (Plate1). 


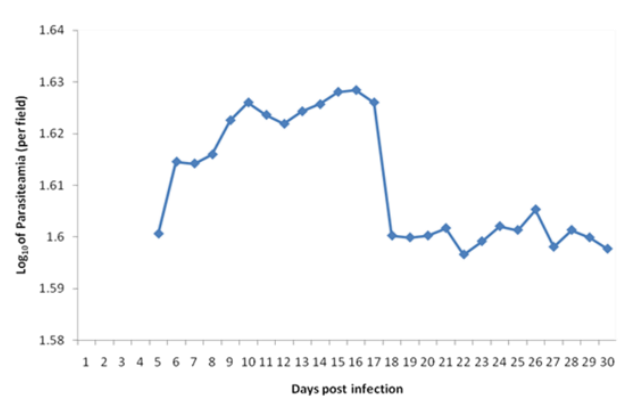

Figure1: Parasitaemia in T. congolense infected sheep 30 days' post infection

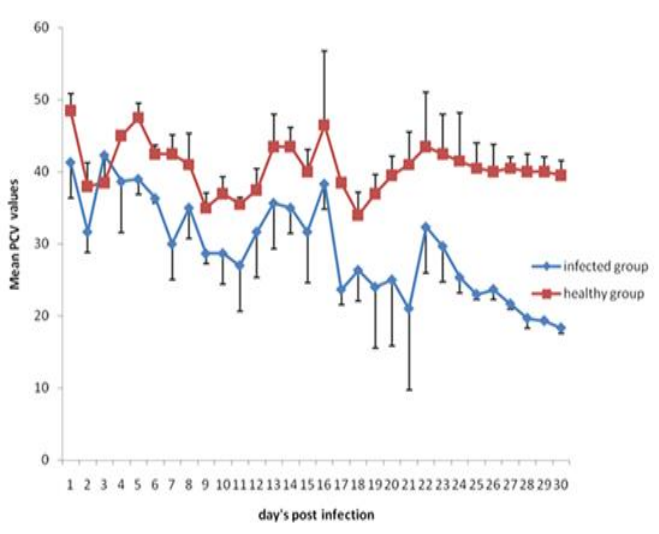

Figure 2: Daily mean PCV of $T$. congolenseinfected and non-infected sheep

Table 1: Mean PCV of T. congolense infected and non-infected sheep.

\begin{tabular}{cll}
\hline Weeks post-infection & $\begin{array}{l}\text { GROUPS } \\
\text { Infected }\end{array}$ & Non-infected \\
\hline 1 & $37.05 \pm 4.69^{\mathrm{a}(\mathrm{a})}$ & $43.21 \pm 4.08^{\mathrm{a}(\mathrm{b})}$ \\
2 & $31.67 \pm 3.61^{\mathrm{b}(\mathrm{a})}$ & $39.00 \pm 3.63^{\mathrm{a}, \mathrm{b}(\mathrm{b})}$ \\
3 & $27.14 \pm 5.93^{\mathrm{b}, \mathrm{c}(\mathrm{a})}$ & $39.50 \pm 3.85^{\mathrm{a}, \mathrm{b}(\mathrm{b})}$ \\
4 & $25.05 \pm 5.49^{\mathrm{c}(\mathrm{a})}$ & $41.21 \pm 1.35^{\mathrm{a}, \mathrm{b}(\mathrm{b})}$ \\
5 & $18.83 \pm 0.71^{\mathrm{d}(\mathrm{a})}$ & $39.75 \pm 0.35^{\mathrm{b}(\mathrm{b})}$ \\
\hline
\end{tabular}

The data are expressed as mean $\pm S D(n=3)$. Values with different superscripts within a column (Post hoc analysis) and between columns (in bracket) are significant different $(p<0.05$ )

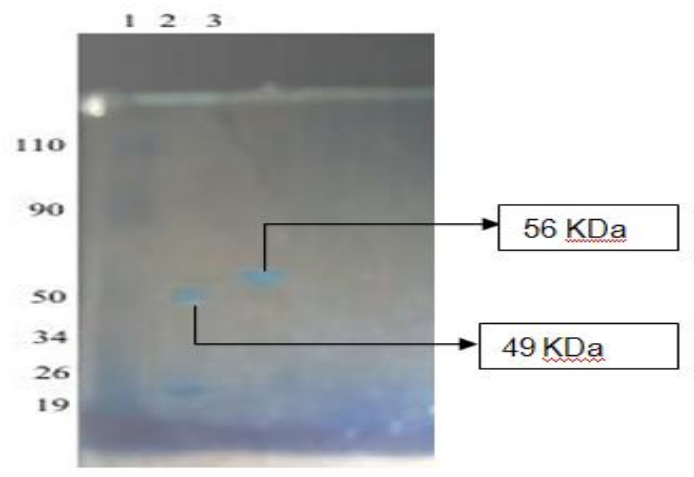

Plate1: SDS-PAGE to determine molecular weight of partially purified ST isolated from thyroid glands of sheep in the experimental groups.

Key: well 1 = Protein molecular weight marker; well $2=$ partially purified ST isolated from $T$. congolense infected sheep; well 3 = partially purified ST from non-infected sheep. 
Baraya et al: Clinicopathological Parameters and Sialyltransferase Activity in Trypanosoma.

Table 2: Purification scheme of ST Enzyme isolated from thyroid tissue of $T$. congolense-infected and non-infected sheep

\begin{tabular}{|c|c|c|c|c|c|c|c|c|c|c|c|c|}
\hline \multirow[t]{2}{*}{$\begin{array}{l}\text { PURIFICATIO } \\
\text { N STEPS }\end{array}$} & \multicolumn{2}{|c|}{$\begin{array}{l}\text { VOLUME } \\
\text { (ML) }\end{array}$} & \multicolumn{2}{|c|}{$\begin{array}{l}\text { PROTEIN } \\
\text { (MG) }\end{array}$} & \multicolumn{2}{|c|}{$\begin{array}{l}\text { ACTIVITY } \\
\text { (U) }\end{array}$} & \multicolumn{2}{|c|}{ YIELD (\%) } & \multicolumn{2}{|c|}{$\begin{array}{c}\text { SPECIFIC } \\
\text { ACTIVITY } \\
\text { (U/MG) }\end{array}$} & \multicolumn{2}{|c|}{$\begin{array}{l}\text { PURIFICATION } \\
\text { FOLD }\end{array}$} \\
\hline & IG & NG & IG & NG & IG & NG & IG & NG & IG & NG & IG & NG \\
\hline $\begin{array}{l}\text { Triton } \\
\text { extraction }\end{array}$ & 14.70 & 13.4 & 1700 & 11800 & 922 & 1966 & 100.0 & 100 & 0.542 & $\begin{array}{l}0.16 \\
7\end{array}$ & 1.0 & 1.0 \\
\hline$\left(\mathrm{NH}_{4}\right)_{2} \mathrm{SO} 4$ & 6.80 & 4.47 & 218 & 1073 & 670 & 1311 & 72.2 & 66.7 & 3.073 & 1.22 & 5.7 & 7.3 \\
\hline $\begin{array}{l}\text { DEAE- } \\
\text { Cellulose }\end{array}$ & 0.95 & 0.75 & 19 & 25.03 & 211 & 430 & 22.9 & 21.1 & 11.11 & $\begin{array}{l}17.2 \\
0\end{array}$ & 20.5 & 103.0 \\
\hline $\begin{array}{l}\text { Sephadex G- } \\
100\end{array}$ & 0.14 & 0.24 & 0.26 & 0.357 & 153 & 270 & 16.6 & 13.7 & 566.67 & $\begin{array}{l}756 . \\
3\end{array}$ & $\begin{array}{l}1045 . \\
5\end{array}$ & 4528.0 \\
\hline
\end{tabular}

Key: IG = Infected group; NG = Non-infected gro

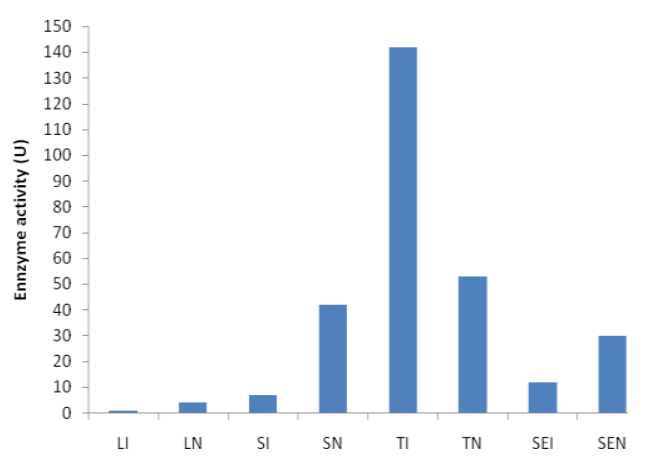

Figure 3: ST enzyme activities in crude extracts from selected organs and serum samples obtained from $T$. congolense infected and non-infected sheep.ST activity was obtained in duplicates.
Key: LI = Liver infected group; LN = Liver non-infected group; SI = Salivary gland infected group; $\mathrm{SN}=$ Salivary gland non-infected group; $\mathrm{TI}=$ Thyroid gland infected group; $\mathrm{TN}=$ Thyroid gland noninfected group; SEI = Serum infected group; SEN = Serum noninfected group.

\section{Crude Enzyme Activity in the Thyroid and Salivary Glands, Liver and Serum}

ST activities were detected in the thyroid and salivary glands, liver and serum (Figure 3). However, the thyroid gland of $T$. congolenseinfected group had the highest ST activity of $142 \mathrm{U} / \mathrm{ml}$. 


\section{$\mathrm{pH}$ and Optimum Temperature}

The optimal pH of ST isolated from thyroid gland of $T$. congolense-infected and non-infected groups were 4.5 and 6.5 , respectively (Figure $4 a$ ). The optimum temperature of ST isolated from $T$. congolense-infected and non-infected groups were $51^{\circ} \mathrm{C}$ and $39^{\circ} \mathrm{C}$, respectively (Figure $4 \mathrm{~b}$ ).

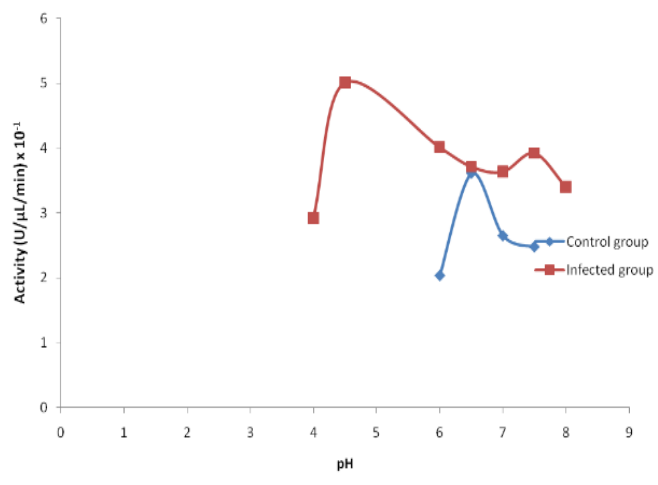

(a)

\section{Activation Energy $\left(\mathrm{E}_{\mathrm{a}}\right)$}

The activation energies of ST from $T$. congolense-infected and non-infected groups were $9.10 \mathrm{~kJ} / \mathrm{mol}$ (Figure $5 \mathrm{a}$ ) and $1.84 \mathrm{~kJ} / \mathrm{mol}$ (Figure

$5 b)$,

respectively.

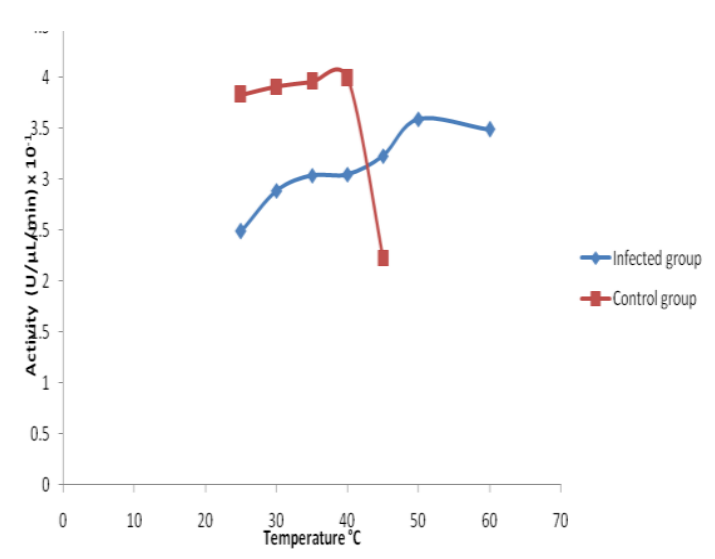

(b)

Figure 4: Optimum $\mathrm{pH}$ (a) and temperature (b) for ST catalytic stability isolated from thyroid gland of $T$. congolense-infected and non-infected sheep

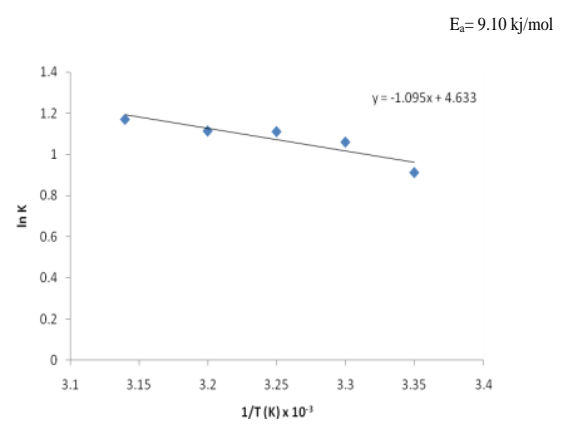

(a) Infected

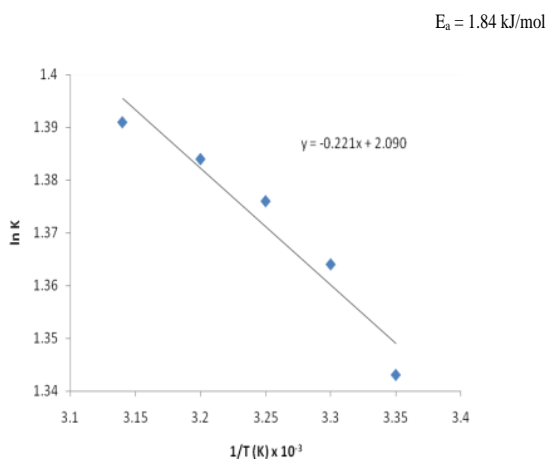

(b) Non-infected

Figure 5: Activation energy of partially purified sialyltransferase from thyroid gland of $T$. congolense infected group and non-infected sheep.

\section{Kinetic Studies}

The $K_{M}$ and $V_{\max }$ values of the partially purified sialyltransferases from thyroid gland of $T$. congolense-infected and non-infected groups are presented in Figure $6 \mathrm{a}$ and $6 \mathrm{~b}$, respectively. For the $T$. congolense-infected group the $K_{M}$ and $V_{\max }$ were $7.19 \mu \mathrm{M}$ and $6.494 \mathrm{mM} / \mathrm{min}$, respectively. While $K_{M}$ and $V_{\max }$ of the non-infected group were $0.769 \mu \mathrm{M}$ and $2.39 \mathrm{mM} / \mathrm{min}$, respectively. 


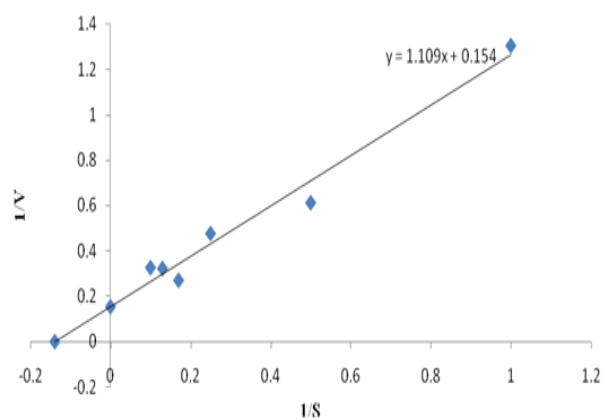

(a) Infected

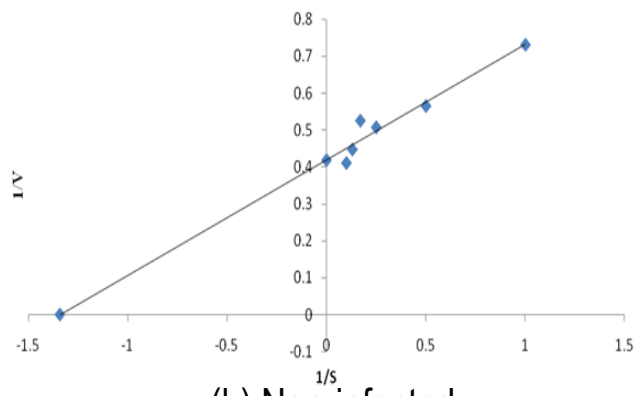

(b) Non-infected

Figure 6: Line-Weaver Burk plot for $\mathrm{K}_{\mathrm{M}}$ and $\mathrm{V}_{\max }$ of ST isolated from thyroid gland of $T$. congolense-infected sheep and non-infected sheep.

\section{DISCUSSION}

The parasitaemia observed on day 5 postinfection with $T$. congolense in sheep was in agreement with the reports of Taylor and Authie (2004) and CSFPH (2018). In this study, there was continuous presence of trypanosomes at detectable levels until peak parasitaemia developed on day 16. The reduction in PCV was statistically significant $(p<0.05)$ between $T$. congolense-infected and non-infected sheep, suggesting haemolytic characteristics of $T$. congolense. Hence, in this study progressive anaemia followed increase in parasitaemia as reported earlier (Esievo et al., 1982; Sekoni et al., 1990; Nok and Balogun, 2003), where more erythrocytes were lysed in the acute phase of the infection. Anaemia has remained an important feature of clinical trypanosomosis (Luckins, 1992; Ogunsanmi and Taiwo, 2004) and also the cause of most tissue and organ degenerations (Ekanem and Yusuf, 2008; Akanji et al., 2009). The lowest PCV observed in $T$. congolense-infected sheep in the present study, could be due to the activity of SD produced by the trypanosomes (Esievo, 1979; Pereira, 1983) that cleaved erythrocytes surface SA (Esievo et al.,1982; Umar et al., 2003; Useh et al., 2006) from the non-reducing end of galactose residues (Angata and Varki, 2002).

Sialyltransferase activity of the thyroid gland of $T$. congolense-infected animals was much higher than observed in the other selected organs harvested from the experimental animals. The findings were in close association with the report of Joseph and Sherry, (2000) who found highest activities of some sialyltransferases in mucin rich submandibular gland. In the present study, ST in the thyroid gland was probably activated during trypanosome infection, while STs in the liver, salivary gland and serum were deactivated or destroyed during infection.

The influence of $\mathrm{pH}$ as observed in this study showed distinct differences in catalysis of sialic acid. Sialyltransferase isolated from the $T$. congolense-infected sheep showed optimum activity at $\mathrm{pH}$ as low as 4.5 . It is possible the physiological response to low $\mathrm{pH}$ induced by the trypanosome infection through the cleavage of available SA for the parasite's metabolism is the increase synthesis of ST isoforms (enzyme yield $16.6 \%)$ from thyroid gland of $T$. congolenseinfected sheep unlike ST isolated from thyroid gland of non-infected sheep (yield 13.7\%) that showed activity around neutrality ( $\mathrm{pH}$ 6.8-7.1). Sticher et al. (1988) reported that pH studies in enzymes generally are functions of the ionization effects of the various amino acids interacting to assume a tertiary globular structure of the enzyme protein. This in turn plays a role in defining the final ionic charges in the binding as well as active sites of the enzyme, a major requirement in enzyme catalysis. A sub-cellular build-up of sialic acid in trypanosome infection may cause $\mathrm{pH}$ changes which in turn affects the 


\section{Nigerian Journal of Basic and Applied Science (December, 2021), 29(2):102-111}

catalytic stability of STs. Interestingly, The $\mathrm{K}_{\mathrm{M}}$ and $V_{\max }$ as determined in this study suggests STs isolated from infected animals to be less active or dormant at low substrate (sialic acid) concentrations in non-disease state and more efficient during disease condition where there is high concentration of the substrate (accompanied by a low blood $\mathrm{pH}$ ) resulting from activity of trypanosomal sialidase. In speculatory terms, the non-infected group may have no immediate subcellular requirement for enzymes that catalyze at higher $\mathrm{K}_{\mathrm{M}}(0.769)$ and $\mathrm{V}_{\max }(2.39)$ since the more sensitive STs may quite sufficiently play the role of sialic acid sialylation of terminal glycans of glycoconjugates (Kono et al., 1997; Joseph and Sherry, 2000). This finding is in agreement with various studies that have shown the $K_{M}$ and $V_{\max }$ of sialyltransferases in non-diseased conditions fall within the range of $10^{-1}$ to $10^{-9}$. The release of $\mathrm{SA}$ into lysosome of vertebrate cell is transported back into the cytosol allowing the SAs to be neutralized or degraded (Harduin-Lepers et al., 1995; Angata and Varki, 2002). SA could also be re-cycled to generate cytidine monophosphatesialic acid (CMP-SA) by cytidine triphosphate activation pathway (Kean, 1991).

Increase in body temperature has been shown to be a trend in trypanosomosis (Taylor and Authie, 2004), a physiological state that further stabilizes sialyltransferase isoforms as observed in $T$. congolense-infected animals which were most active at temperatures between $49{ }^{\circ} \mathrm{C}-51^{\circ} \mathrm{C}$ in vitro. It is of interest to note that the activation energies as calculated for the enzymes suggest sialyltransferase isolated from $T$. congolenseinfected group had higher $E_{a}(9.10 \mathrm{~kJ} / \mathrm{mol})$ which probably explains the corresponding high $\mathrm{Km}$ which is a function of substrate concentration necessary for enzyme activation. The ST in the non-infected group requires less $\mathrm{E}_{\mathrm{a}}(1.84 \mathrm{~kJ} / \mathrm{mol})$ and thus favored under normal conditions. The resialylation phenomenon mediated by predominance of ST isoforms stable at low pH and high SA concentrations probably explains the increase in survival rates of some trypano- susceptible breeds of animals that survive anaemia in trypanosomiasis (Esievo et al., 1986).

Molecular weights of the enzymes isolated from the thyroid gland of $T$. congolense-infected and non-infected groups as estimated were $49 \mathrm{KDa}$ and $56 \mathrm{KDa}$, respectively. This is in agreement with the findings of Sticher et al. (1991) and Takeshi et al. (2007). Sialyltransferases have been shown to exist as isoforms (Kitagawa et al., 1996; Taniguchi, et al., 2002), catalyzing similar reaction (Groux-Degroote et al., 2008), and possessing the ability to exist in oligomeric forms. Oligomeric enzymes form close associations that increase catalytic stability and efficiency. The enzyme isolated from thyroid gland of $T$. congolense-infected group may exist as dimer, requiring a subunit which may possibly increase the stability and efficiency of this enzyme in disease conditions.

\section{CONCLUSION}

In this study, sialyltransferase from thyroid gland of Trypanosoma congolense-infected and noninfected control sheep was isolated, partially purified and characterized. The enzymes from both groups showed marked variability in $\mathrm{pH}$, temperature, activation energy, kinetic constants and molecular weights. In general, the high sialyltransferase activities observed in the thyroid gland of $T$. congolense-infected sheep coupled with changes in kinetic properties could be the result of a physiological response to parasite's activity in the challenged group. Based on these findings it could be speculated that sialyltransferase exist in different forms, i.e., in disease and normal physiological states. This difference is a powerful tool which could be investigated further for the control of AAT.

\section{ACKNOWLEDGEMENTS}

The authors of this manuscript thank the management of Centre for Biotechnology Research and Training, Ahmadu Bello University $(A B U)$, Zaria, Nigeria for granting access to its facility. We also thank the technical staff of the Clinical Pathology Laboratory, Department of 
Veterinary Pathology, ABU, Zaria, Nigeria for their technical support.

\section{REFERENCES}

Akanji, M. A., Adeyemi, O. S., Oguntoye, S. O., \& Sulyman, F. (2009). Psidium guajava extract reduces trypanosomosis associated lipid peroxidation and raises glutathione concentrations in infected animals. Experimental and Clinical Sciences, 8: 148-154.

Alhadeff, J. A., Holzinger, R. T. (1979). Solubilization and stabilization of human liver glycoprotein sialyltransferase. Biochimica et Biophysica Acta, 570: 56-64.

Angata, T., \& Varki, A. (2002). Chemical diversity in the sialic acids and related a-keto acids: an evolutionary perspective. Chemical Reviews, 102: 439-469.

CFSPH (Centre for Food Security and Public Health) (2018). African animal Trypanosomosis. Fact sheet, pp. 1-8.

Ekanem, J. T., \& Yusuf, O. K. (2008). Some biochemical and haematological effects of black seed (Nigella sativa) oil on T. bruceiinfected rats.African Journal of Biomedical Research, 11: 79-85.

Ellies, L., Dotto, D., Levy, G. G., Wahrenbrock, M., Ginsburg, D., Varki, A., Le, D.T., \& Marth, J. D. (2002). Sialyltransfrase ST3GAL-IV operates as a dominant modifier of haemostasis by concealing asialoglycoprotein receptor ligands. Proceedings of the National Academy of Sciences, U.S.A. 2002, 10042-10047.

Esievo, K. A. N. (1979). In vitro production of neuraminidase (sialidase) by Trypanosoma vivax. Proceedings of the 16th meeting of OAU/STRC International Council for Trypanosomosis Research and Control, Yaounde, Cameroon, 1979: 205-210.

Esievo, K. A. N., Saror, D. I., llemobade, A. A., \& Hallaway, M. H. (1982). Variation in erythrocyte surface and free serum sialic acid concentrations during experimental Trypanosoma vivax infection in cattle. Research in Veterinary Science, 32: 1-5.
Esievo, K. A. N., Saror, D. I., Kolo, M. N., \& Eduvie, L. O. (1986). Erythrocyte surface sialic acid concentrations in N'Dama and Zebu cattle. Journal of Comparative Pathology, 96: 95100.

Groux-Degroote, S., Harduin-Lepers, A., \& Delannoy, P. (2008). Biosynthesis of mucin O-glycan chains in normal and pathological states. In: Van Seuningen I, Ed. The epithelial Mucins: Structure/Function. Roles in Cancer and Inflammatory Diseases. Kerala, India: Research Signpost. pp. 3954.

Harduin-Lepers, A., Recchi, M. A., \& Delannoy, P. (1995). 1994, the year of sialyltransferases. Glycobiology, 5: 741-758.

Hidari, I. P. J. K., Horie, N., Murata, T., Miyamoto, D., Suzuki, T., Usui, T., \& Suzuki, Y. (2005). Purification and characterization of a soluble recombinant human ST6Gal 1 funtionally expressed in Escherichia coli. Glycoconjugate Journal, 2: 1-11.

Joseph, T. Y. L., \& Sherry, A. W. (2000). Sialyltransferases: In Carbohydrates in Chemistry and Biology Beat E., Gerald, W. Hart, P. S. (Ed.). Wiley-VCH Verlag GmbH Germany. pp. 213-226,

Kean, E. L. (1991). Sialic acid activation. Glycobiology, 1: 441-447.

Kitagawa, H., Mattei, M. G. and Paulson, J. C. (1996). Genomic organization and chromosomal mapping of the Gal beta 1,3GalNAc/Gal beta 1,4GIcNAc alpha 2,3sialyltransferase. Journal of Biological Chemistry, 271: 931-938.

Kono, M., Ohyama, Y., Lee, Y. C., Hamamoto, T., \& Kojima, N. (1997). Mouse beta-galactoside alpha 2,3-sialyltransferases: comparison of in vitro substrate specificities and tissue specific expression. Glycobiology, 7: 469-479.

Křen, V., \& Thiem, J. (1997). Simple and nonradioactive method for determination of sialyltransferase activity. Biotechnology Techniques, 11: 323-326.

Luckins, C. A. (1992). Protozoal diseases of camels In: Proceedings of First International Camel Conference, United Arab Emirates, 1992: 23-27. 


\section{Nigerian Journal of Basic and Applied Science (December, 2021), 29(2):102-111}

Nok, A. J., \& Balogun, E. O. (2003). A bloodstream Trypanosoma congolense sialidase could be involved in anaemia during experimental trypanosomosis. Journal of Biochemistry, 133: 725-730.

Ogunsanmi, A. O., \& Taiwo, V. O. (2004). Comparative studies on erythrocyte calcium, potassium, haemoglobin concentration, osmotic resistance and sedimentation rates in grey duiker (Sylvicapragrimmia), sheep and goats experimentally infected with Trypanosoma congolense. Journal Veterinarski Arhiv, 74: 201-216.

Paltrinieri, S., Rossi, G., Meregalli, A., Stefanello, D., Pecile, A., Moretti, P., \& Rondena, M. (2012). Sialic acid and sialyltransferase activity in serum and tissues of dogs with mammary tumors. Veterinary Pathology, 49(4): 669-681

Pereira, M. E. A. (1983). A developmentally regulated neuraminidase activity in Trypanosoma cruzi. Science, 219: 14441446.

Porter, C. W., \& Bernacki, R. J. (1975). Ultrastructural evidence for ectoglycosyltransferase systems. Nature, 256: 648-650.

Abubakar A., Samdi, S. M., Abenga, J. N., Haruna, M. K., Wayo, B. M., Fajinmi, A. O., Sumayin, H. M., Usman, A. O., Hussaina, J. Z., Muhammad, H., Yarnap, J. E., Ovbagbedia, R. P., \& Abdullahi, R. A. (2010). Impact of trypanosomosis on food security in Nigeria: A review. International Journal of Animal and Veterinary Advances, 2: 47-50.

Sekoni, V. O., Saror, D. I., Njoku, C. O., KumiDiaka, J., \& Opaluwa, G. I. (1990). Comparative haematological changes following Trypanosoma vivax and Trypanosoma congolense infections in Zebu bulls. Veterinary Parasitology, 35: 1119.

Sticher, U., Gross, H. J., \& Brossmer, R. (1988). Purification of alpha 2, 6-sialyltransferase from rat liver by dye chromatography. Journal of Biochemistry, 253: 577-580.
Sticher, U., Gross, H. J., \& Brossmer, R. (1991). Purification and characterization of a(2-6)sialyltransferase from human liver. Journal of Glycoconjugate, 8: 45-54.

Sulaiman, F. A., \& Adeyemi, O. S. (2010). Changes in haematological indices and protein concentrations in Trypanosoma brucei infected rats treated with homidium chloride and diminazene aceturate. Experimental and Clinical Sciences, 9: 3945.

Takeshi, Y., Yoko, H., Masako, I., Hitomi, K., Toshiki, M., Hiroshi, T., \& Yoshimitsu, T. (2007). A $\quad \beta$-galactoside a2,6sialyltransferase produced by a marine bacterium, Photobacterium leiognathiJTSHIZ-145, is active at pH 8. Glycobiology, 17(11): 1167-1174.

Taniguchi, N., Honke, K., \& Fukuda, M. (2002). Handbook of glycosyltransferases and related genes (1st Ed.), Springer-Verlag: Tokyo, Japan. pp. 267-356.

Taylor, K., \& Authie, E. M. L. (2004). Pathogenesis of animal trypanosomosis. In: The trypanosomiases. Maulin I, Holmes PH, Miles M A (Eds.), CABI Publishing,UK. pp. 331-353.

Umar, I. A., Sadiq, G. S., \& Esievo, K. A. N. (2003). The effect of Trypanosoma congolense infection on free and membrane bound sialic acid levels in blood and tissues of rabbits. Nigerian Journal of Biochemistry and Molecular Biology, 18: 43-46.

Useh, N. M., Ajanusi, J. O., Esievo, K. A. N., \& Nok, A. J. (2006). Characterization of a sialidase (neuraminidase) isolated from Clostridium chauvoei (Jakari strain). Cell Biochemistry and Function, 24: 347-352.

Wang, P. H., Lo, W. L., Hsu, C. C., Lin, T. W., Lee, W. L., \& Wu, C. Y., (2001). Different enzyme activities of sialyltransferases in gynecological cancer cell lines. European Journal Gynaecological Oncology, 23(3): 221-226.

WHO (World Health Organization) (18 $8^{\text {th }}$ May, 2021). Trypanosomiasis, human African (sleeping sickness). 